\title{
DEVELOPMENT OF A COMBINE HARVESTER FOR MEXICAN TEOSINTE CROP
}

\author{
EL-YAMANI, A.E., A.E. EL-SHAZLY and W.F. EL-METWALLY
}

Ag. Eng. Res. Inst., (AEnRI) ARC, Dokki, Giza, Egypt

(Manuscript received 20 August 2014)

\begin{abstract}
A new combine header designed and fabricated set up on local combine axial flow constructed by AENRI to determine the perfect performance and decreasing both of combine losses and operation cost. The modified combine was tested under four forward speeds of $1.7,1.9,2.2$ and $2.4 \mathrm{~km} / \mathrm{h}$, four drum speed of $12.39,15.7,17.01$ and $18.32 \mathrm{~m} / \mathrm{s}$, and three cutting height of 5,15 and $25 \mathrm{~cm}$, respectively. The obtained results show that, the modified combine gave the best results at $1.9 \mathrm{Km} / \mathrm{h}$ forward speed, $15.7 \mathrm{~m} / \mathrm{s}$ drum speed and $25 \mathrm{~cm}$ cutting height, where the maximum effective field capacity of 1.66 fed/h, field efficiency of $69.1 \%$. and the maximum grain out put of $1.144 \mathrm{Mg} / \mathrm{h}$. On the other hands, minimum energy consumed of 25.87 $\mathrm{kW} . \mathrm{h} / \mathrm{fed}$, minimum of total losses and total grain damage of 5.41 and $0.41 \%$ respectively are obtained.

Keywords. Mexican Teosinte grains, effective field capacity, field efficiency, grain output, total grain losses, total grain damage, energy consumption.
\end{abstract}

\section{INTRODUCTION}

Rayana corn (Mexican Teosinte) is an annual, warm-season grass introduced from Mexico. It is similar to corn in general vegetative appearance and stands of 150 to $250 \mathrm{~cm}$ in height. It is coarse, branches at the base, and the leaf blades are swordshaped to $6 \mathrm{~cm}$ wide and 20 to $50 \mathrm{~cm}$ long. Clusters of slender "ears" (seed pods) are produced in each of the 5 to 7 uppermost leaf axils. Teosinte plants are so similar to maize in outward appearance (stalk, leaves, and terminal tassel) that the casual observer might mistake them for corn (Wilkes, 2004). Teosinte ears bear only about 10 kernels, enclosed in rough cellulose-lignin structures known as fruit cases, in contrast, maize ears can bear 50 or more uncovered kernels attached to the central axis of the ear. At maturity, the teosinte ear disarticulates such that the individual fruit cases become the dispersal units (Wilkes, 1997). It is adapted to fertile soils ranging from somewhat poorly to well drain. It can grow wherever corn is grown.

Conventional harvesting of Rayana corn was carried out by mowing manually and threshing under tractor's wheels. This resulted in reducing crop yield and damaged its seeds. whatever the mechanical harvesting is more efficient the traditional methods of harvesting. By the way the forage department at Gimaiza research station cultivated for seeds production. Medium size of combine harvester 
developed by AENRI was applied to harvest that crop. The results reveal that increasing shoots leg with a lack ratio of grain weight to the weight of the shoot, which lead to increase the proportion of grain loss with a straw out of the machine whereas the loss can be inspected at a low reel speed or by clogging the auger of the header or by increasing the speed of air cleaning fan. Consequently combine machine is to upgrade to develop to reduce the loss rate as much as possible. Elyamani, et al (2012) make an experiment in West Nubaria by using combine harvesting machine after making some modifications to improve the performance of header unit to harvest alfalfa crop with increase productivity and minimize losses. The results indicated that, both of field capacity, field efficiency and Productivity for developed header were agreed directly with forward speed, reel speed and cutter bar speed. Ramesh et al. (1980) reported that, shatter loss at the self-propelled combine header is a major part of total alfalfa grain harvesting losses. These losses were measured to be as high as $400 \mathrm{~kg} / \mathrm{ha}$ in high-yielding fields which are about 25 to $30 \%$ of the grain yields obtained. Many crops, environmental condition. Mosby (1995) mounted an additional sickle bar cutter on the back side of a combine header. The sickle bar was supported by tracking arms and suspension springs allowing the cutter to float along the ground surface while the combine harvester was in operation. Siebenmorgen et al. (1994) mentioned that, total grain yields were calculated from data collected with a commercial combine and a plot combine. Loss rates were estimated and compared using two techniques. The first technique used the total grain yield determined from the commercial combine to calculate loss rates. The second technique used the total grain yield determined the plot combine and the amount of grain collected in the grain tank of the commercial combine to calculate loss rates. Differences of as large as $50 \%$ points were observed in some test runs between the two techniques. Oliveira et al. (2005) stated that the mechanical damage caused by the rotation of threshing cylinder and moisture content of maize seeds at harvest may affect the germination and vigor. In direct-cut cases, all header losses are considered gathering losses. Factors effecting header losses are (1) cutting height, (2) reel position with respect to the cutter bar, and (3) reel speed with respect to the forward speed. They stated that peripheral speed, mentioned that recommended to be about $25 \%-50 \%$ faster than the forward speed of the combine. Mazaheri, (1997) header loss depends on: reel rotational speed and ground speed and cutting bar knives. Reel rotational speed and ground speed are mostly efficacious and it can be shown that their losses are 0.5 to $2 \%$ of field yield. Mostofi (2011) showed reel wheel should be placed in $15-25 \mathrm{~cm}$ above the cutter bar, also, cutting height should be lower than lowest size of crop, furthermore, the reel speed should be adjust about 1.5- 1.25 of ground speed. 
Hassani et al. (2011) stated that grain losses induced from platform in JD1165 combine gained $1.29 \%$ and losses at the back of the combine was $0.96 \%$ on average in seven repetitions. As the results showed, the achieved amounts were in the range of acceptable ones. On the other hand, since reduction in the platform losses follows considerable decrease in losses cost, converting the forward mechanism into hydrostatic one would cause less vibration and provide more control on forward speed and as a consequence would decrease the amount of losses ascribed to the platform. They added too, the amount of broken grains in the JD1165 combine as demonstrated, gained a remarkable amount. This is mainly attributed to the imprecise adjustments of the threshing unit such as the cylinder speed and the space between the cylinder and concave. Harvest begins when grains are mature and pods and plant material are thoroughly dried. A standard combine is used to pick up the crop in the windrow, or harvest the whole plant standing in the field and thresh the grain from the pod. Damaged grain will not germinate. Losses during harvest depend on a number of factors, such as field conditions, crop conditions, machine adjustments, and operation. The grain is transferred from the combine into boxes on trucks and is then taken to the conditioning facility for cleaning and bagging (Mueller, 2008). Silberstein et al. (2010) found that, grain moisture content was the most reliable indicator of grain maturity and harvest timing in grass grain crops. There are two significant times during harvest that knowledge of grain moisture is critical: at swathing and at combining. Swathing within the correct range of grain moisture content will maximize grain yield and minimize grain losses during harvest. Taking an accurate measurement of grain moisture content is a key component of economic grass grain crop management than $4 \%$ of the inflorescences were still unripe. It is concluded that the optimum time to harvest red clover for grain production is about three or four weeks after the end of the period of rapid inflorescence production and that this coincides with the time when only a small proportion of unripe inflorescences remain. Therefore, the objectives of this research were to:

1 - Introduction modified header to fit combine for harvesting Mexican Teosinte grains with reduced rates of loss to allowable limits.

2 -Testing machine after adjustment for determining the rate of performance parameters to determine the optimum conditions of operation on field.

\section{MATERIALS AND METHODS}

AENRI (2007) developed and fabricated axial flow medium size combine harvester. A local combine harvester confidential to combine wheat, barley and rice 
with average harvesting losses did not exceed $4 \%$. On farm trails were conducted to harvest rayana corn but obtained results were bad. It is imperative to modify the header of local combine harvester. The main experiments were carried out at the experimental farm of Gimaza Research Station, El-Gharbia governorate during season 2013 on experiment area about two feddans, to investigate the performance and determined different combine losses. Table1 summarized some of physical properties of rayana corn (Mexican Teosinte) plants.

Table 1. Some physical properties of Mexican Teosinte (Zea mays. L variety) plants.

\begin{tabular}{|c|c|c|c|c|c|c|}
\hline $\begin{array}{c}\text { No. of } \\
\text { sample }\end{array}$ & $\begin{array}{c}\text { Plants } \\
\text { length, cm }\end{array}$ & $\begin{array}{c}\text { Plants diameter, } \\
\mathrm{cm}\end{array}$ & $\begin{array}{c}\text { No. of } \\
\text { plant ears }\end{array}$ & $\begin{array}{c}\text { Mass of grain } \\
\text { plant, g }\end{array}$ & $\begin{array}{c}\text { Plant } \\
\text { weight, g }\end{array}$ & $\begin{array}{c}\text { Grain / } \\
\text { straw ratio }\end{array}$ \\
\hline 1 & 185 & 2.15 & 7 & 39 & 113 & $1: 2.89$ \\
\hline 2 & 191 & 1.80 & 6 & 46 & 91 & $1: 1.98$ \\
\hline 3 & 205 & 1.75 & 7 & 28 & 85 & $1: 3.04$ \\
\hline 4 & 188 & 2.08 & 8 & 35 & 108 & $1: 3.08$ \\
\hline 5 & 196 & 1.65 & 6 & 31 & 99 & $1: 3.19$ \\
\hline mean & 193 & 1.88 & 6.8 & 35.8 & 99.2 & $1: 2.84$ \\
\hline
\end{tabular}

\section{Combine harvester before developed:}

Fig (1) and Table (2) show the main components of a local combine and indicated the combine header before modified. Combine has axial-flow threshing and straw separation units, which are better in handling wet straw and do not require straw walkers for separating the straw. Other advantages of the axial flow concept are higher throughput and gentler treatment of fragile grains, which are often cracked by the faster rotational speeds of conventional combine threshing cylinders.

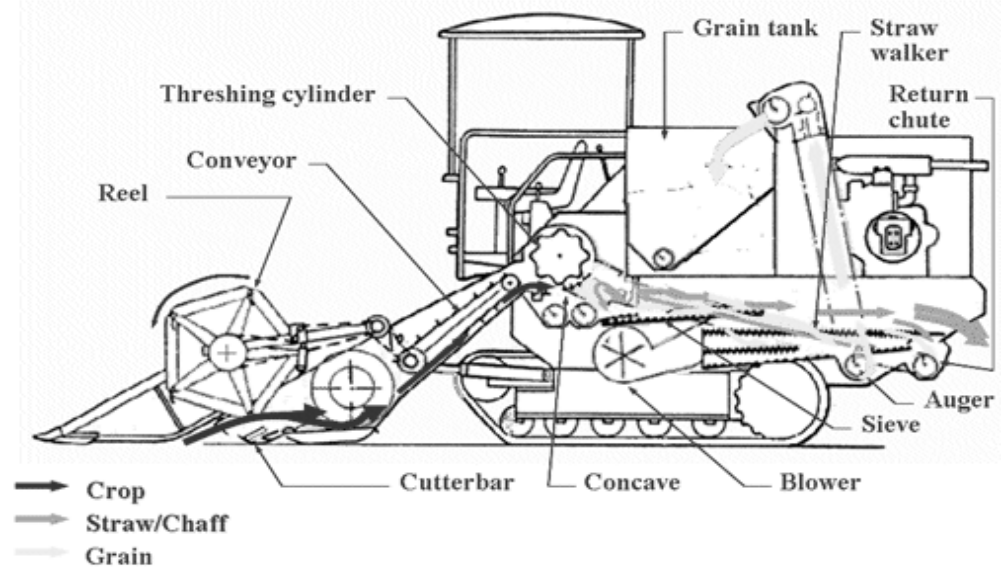

Fig. 1. Diagram scheme of combine harvester before modification. 
Table 2. Specification of used grain combine harvester

\begin{tabular}{|l|l|l|}
\hline No. & \multicolumn{1}{|c|}{ Item } & \multicolumn{1}{c|}{ Value } \\
\hline 1 & Cutting width, mm & 2100 \\
\hline 2 & LX W X H, mm & $4560 \times 2100 \times 3650$ \\
\hline 3 & Capacity of grain tank, kg & 1000 \\
\hline 4 & Engine power, $\mathrm{kW}$ & $43(58 \mathrm{hp})$ \\
\hline 5 & Total weight, $\mathrm{kg}$ & 2280 \\
\hline 6 & Reel diameter, mm & 1150 \\
\hline 7 & Cutter stroke, mm & 76.2 \\
\hline 8 & Reel type & Eccentric teeth platform- type \\
\hline 9 & Reel rod number & 5 \\
\hline 10 & Harvester screw diameter, $\mathrm{mm}$ & 490 \\
\hline
\end{tabular}

\section{Combine harvester after developed:}

The general modification parts carried out on the combine header and some adjustments were made to suit the harvesting and threshing Mexican Teosinte corn as follows:

1- Manufacturing a new header are presented and sketched in Fig. 2. which is characterized by harvesting a stalks which should reach up to 2 meters lenght.

2- Manufacturing new reel to suit high lengths in crop, with a diameter of $50 \mathrm{~cm}$ installed on the perimeter of the five beams mounted on each one of them 13 glands fork with of $20 \mathrm{~cm}$ length, diameter of $3 \mathrm{~cm}$ and spacing apart of $16 \mathrm{~cm}$ as shown in Figs. 3 and 4.

3- Installation of gear box to control in the rotation reel speed required for harvest.

4- Replace the reel arms by another longer with $180 \mathrm{~cm}$ length to direct cutter bar to cut different the lengths of crop shown in Fig. 2.

5- Replace normal hydraulic of the reel piston by other piston which can run as high as $170 \mathrm{~cm}$ as shown in Figs. 2.

6- Installation of horizontal separator between the treads of the crop mat lifting from header to threshing room to prevent wrap around the poles of the chains and gears.

7- Setting threshing rasp bar axial cylinder and adjusting them to fit threshing the Mexican Teosinte corn ears as shown in Fig. 5.

8- Setting other parts of combine like sieves and cleaning fan speed and lifting augers to fit the size of the Mexican Teosinte corn. 


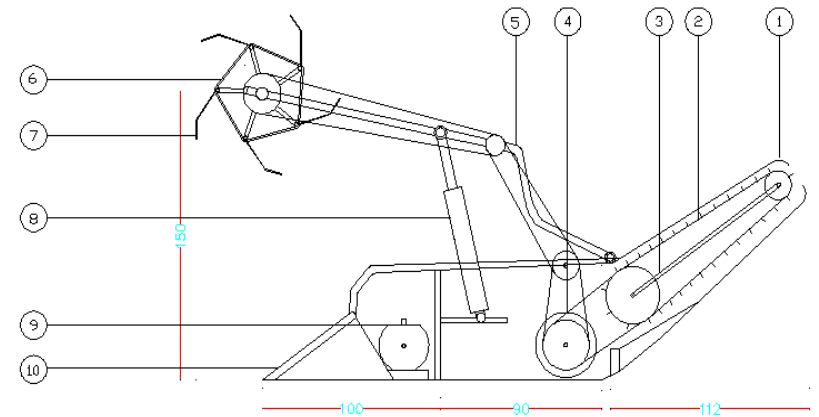

1. Feeder conveyer

2. Conveying mat

3. plate

4. Harvester screw auger

5. Reel bar stay

6. Reel

7. Reel teeth

8. Hydraulic piston

9. Knife gear box

10. Stalk divider

Fig. 2. Schematic diagram of combine harvester header after modification.

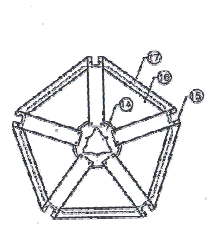

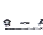

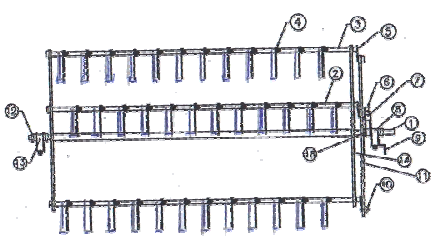

TIITIITIIIII

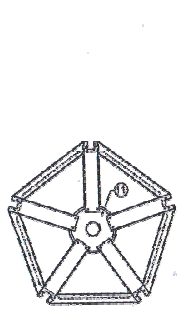

2

3

4 Fork support

5 support

6 Support

7 Cam clutch

8 Reel bearing support support

Bearing corer

flange

Set collar

Reel bearing support

flange

Spider reinforcement arm

Spider plate

support

stay

Fig. 3. Elevation and side view of modifying harvesting reel

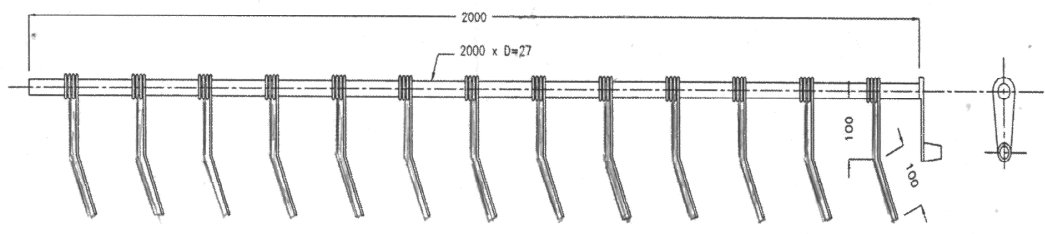

Fig. 4. Modifying of front reel forks 


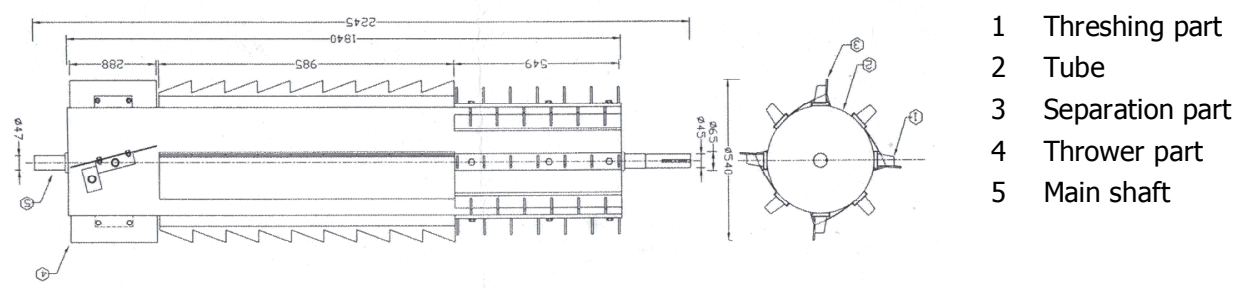

Fig. 5. Threshing rasp bar axial cylinder

\section{Investigated variables:}

The present study was carried out in about two feddans to evaluate the effect of forward speed of $(1.7,1.9,2.2$ and $2.4 \mathrm{~km} / \mathrm{h})$, drum speed of $(12.39,15.7,17.01$ and $18.32 \mathrm{~m} / \mathrm{s})$ and height cutting stalks of $(5,15$ and $25 \mathrm{~cm})$ on combine field capacity, field efficiency, grain output, percentage of total grain damage, total grain losses, energy required. Where forward speed determined by estimated the times which combine run at different distance. Next plotted the curve between the distance as $\mathrm{x}$ axis and time as $y$ axis then selected from the curve the studied speeds. The threshing and separating drum (axial flow) provided with hydraulic motor. So a changing drum speeds from driver cabin.

\section{Measurements:}

1) Effective and theoretical field capacity: The effective field capacity was calculated as follows:

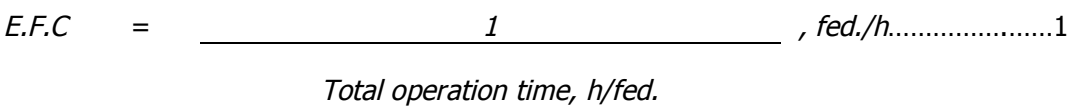

Also, theoretical field capacity was calculated as follows:

Th.F.C = Width of combine, $m \times$ forward speed, $\mathrm{km} / \mathrm{h}$ , fed./h............2

4.2

2) Field efficiency (F.E.): The field efficiency was calculated from the following equation:

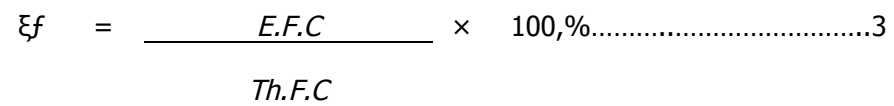

Where:

$$
\begin{array}{ll}
\xi f & =\text { Field efficiency, } \%, \\
\text { E.F.C } & =\text { Effective field capacity, fed } / \mathrm{h}, \text { and } \\
\text { Th.F.C } & =\text { Theoretical field capacity, fed } / \mathrm{h} .
\end{array}
$$


3) Productivity of the machine: It was determined by collecting and weighted yield output from the experimental unit area.

4) Total grain losses: The total losses of combine harvester were those occurred in front, behind the combine and during harvesting operations and it includes the following main sources (NSAE/NCAM/SON, 1995):

Total cutterbar losses, $\%=\frac{\text { Total header losses }, \mathrm{kg} / \mathrm{fed}}{\text { Total yield }, \mathrm{kg} / \mathrm{fed}} \times 100$ $\ldots 4$

Total cutterbar losses (sum of shatter, lodged, stalk and stubble loss).

Unthreshed grain losses, $\%=\frac{\text { Unthreshed grain losses, } \mathrm{kg} / \mathrm{fed}}{\text { Total yield }, \mathrm{kg} / \mathrm{fed}} \times 100$. 5

Threshed grain losses, $\%=\frac{\text { Threshed grain losses, } \mathrm{kg} / \mathrm{fed}}{\text { Total yield }, \mathrm{kg} / \mathrm{fed}} \times 100$ .6

Total losses, $\%=\frac{H_{L}+U_{L}+T_{L}}{H_{L}+U_{L}+T_{L}+T_{Y}} \times 100$

Where:

$H_{L} \quad$ Total header losses, $\mathrm{kg} / \mathrm{fed}$,

$U_{L} \quad$ Unthreshed grain losses, $\mathrm{kg} / \mathrm{fed}$,

$T_{L} \quad$ Threshed grain losses, $\mathrm{kg} / \mathrm{fed}$ and

$T_{Y} \quad$ Total grain yield, $\mathrm{kg} / \mathrm{fed}$.

\section{5) Grain damage (visible and invisible):}

Visible grain damage: It was determined by separating the damage grain by hand from the sample of $100 \mathrm{~g}$ the samples were taken randomly from the threshed grain. The percentage of seed damage was calculated as follows (NSAE/NCAM/SON, 1995):

Visiblegraindamage $\%=\frac{\text { Massof brokengrainsin sample, } g}{\text { Totalmassof grainsin sample, } g} x 100 \ldots \ldots \ldots \ldots . . .8$

Invisible grain damage: A germination test was carried out using Petri dishes. The samples of these tests were taken randomly after separating the damage grain (visible damage). One hundred grains were put in Petri dish on a filter paper, covered 
with water and incubated at $25^{\circ} \mathrm{C}$ for $24 \mathrm{~h}$. The germinated grains were collected from each dish and expressed as a percentage of the original number of seed.

Total grain damage,$\%=($ Visible grain damage,$\%+$ Invisible grain damage,$\%)$ .9

6) Power consumption: The fuel consumption was measured by using an especial device consists of 3 liter graduated cylinder was connected to the fuel pump. The amount of fuel in tube after executing each treatment was recorded. Then Power consumption was calculated according the principles and assumption of Hunt (1983):

$$
\mathrm{EP}=\frac{\mathrm{FC} x \rho \mathrm{f} x \mathrm{LCV} x 427 \times \eta_{\mathrm{m}} \times \eta_{\mathrm{th}}}{3600 \times 75 \times 1.36}, \mathrm{~kW}
$$

Where:

EP Power requirements consumption during the cutting operation, $\mathrm{kW}$,

$F C$ Fuel consumption, $\mathrm{l} / \mathrm{h}$,

$\rho f$ Density of the fuel, $\left(850 \mathrm{~kg} / \mathrm{m}^{3}\right)$,

$L C V$ Lower calorific value of fuel, $(10000 \mathrm{kcal} / \mathrm{kg})$,

427 Thermo mechanical equivalent, $\mathrm{kg} \cdot \mathrm{m} / \mathrm{kcal}$,

$\eta_{m} \quad$ Mechanical efficiency of engine, (80\%) and

$\eta_{t h} \quad$ Thermal efficiency of the engine, (considered to be about 35 for diesel engine).

7) Data analysis: multi factors random complete block design was used as experimental design and computer statistical program named SPSS run the study the effect of elevated parameters on combine performance variables. The main treatment were forward speed (Fs), drum speed (Ds) and cutting height (Ct).

\section{RESULTS AND DISCUSSION}

\section{I) Primordial Test:}

Primary experiment was carried out during summer 2013, to determine total grain losses and total grain damage with harvesting Mexican Tenisnte crop by combine harvester. The effect of forward speed and drum speed on total grain losses and damage were determined. Results indicate that, rate of losses and damage were very high because combine harvester have great cutting height ranged from 25 to $40 \mathrm{~cm}$ above ground surface. Where, the average of length plants was $200 \mathrm{~cm}$. The maximum of grain losses was $16.65 \%$ recorded at forward speed of $2.8 \mathrm{~km} / \mathrm{h}$ and drum speed of $10.8 \mathrm{~m} / \mathrm{s}$ while, maximum of grain damage was $7.67 \%$, recorded at forward speed of $2.8 \mathrm{~km} / \mathrm{h}$ and drum speed of $20.38 \mathrm{~m} / \mathrm{s}$. 


\section{ח) Development combine harvester performance:}

\section{1- Actual Field Capacity and Field Efficiency:}

The results of the analysis of variance indicated that both of actual field capacity and field efficiency were significant at the 0.01 level for combine forward speed and cutting height stalks while drum speed was not significant as shown in Table 3. Also, the interaction between height cutting stalks and forward speed was significant effects while, the interaction between height cutting $x$ drum speed and between forward speed $\times$ drum speed were not significant. Fig. 6 shows the effect of combine forward speed at different of height cutting stalks on both of actual field capacity and field efficiency. The results indicated that, actual field capacity was increased with increasing both of forward speed and height cutting stalks while, field efficiency was decreased with increasing both of forward speed and cutting height. The maximum value of field capacity was $1.66 \mathrm{fed} / \mathrm{h}$ recorded at forward speed of $2.4 \mathrm{~km} / \mathrm{h}$, and height cutting stalks of $25 \mathrm{~cm}$. While, maximum value of field efficiency was $69.1 \%$ recorded at forward speed of $1.7 \mathrm{~km} / \mathrm{h}$, and height cutting stalks of $25 \mathrm{~cm}$.

Fig. 6. Effect of forward speed and height Cutting stalks on actual field capacity, fed/h
and field efficiency, \%.

\section{2- Grain Output:}

Grain output was significantly different at the $1 \%$ level for height cutting stalks, forward speed while drum speed was no significant. On other hand, cutting height stalks $\times$ forward speed and height cutting $\times$ forward speed $\times$ drum speed interactions were high significant. While, interaction between height cutting stalks $\times$ drum speed and between forward speed $\times$ drum speed were significant as shown in Table 3, with coefficient of determination $\left(R^{2}\right)$ of 0.99936 and coefficient of variation of $0.488 \%$. Data presented in Fig. 7 illustrated that, grain output was increased with increasing forward speed and cutting height. The maximum of grain output was $2.05 \mathrm{Mg} / \mathrm{h}$ recorded at forward speed of $2.4 \mathrm{Km} / \mathrm{h}$, drum speed of $17.1 \mathrm{~m} / \mathrm{s}$ and cutting height stalks of $25 \mathrm{~cm}$. 


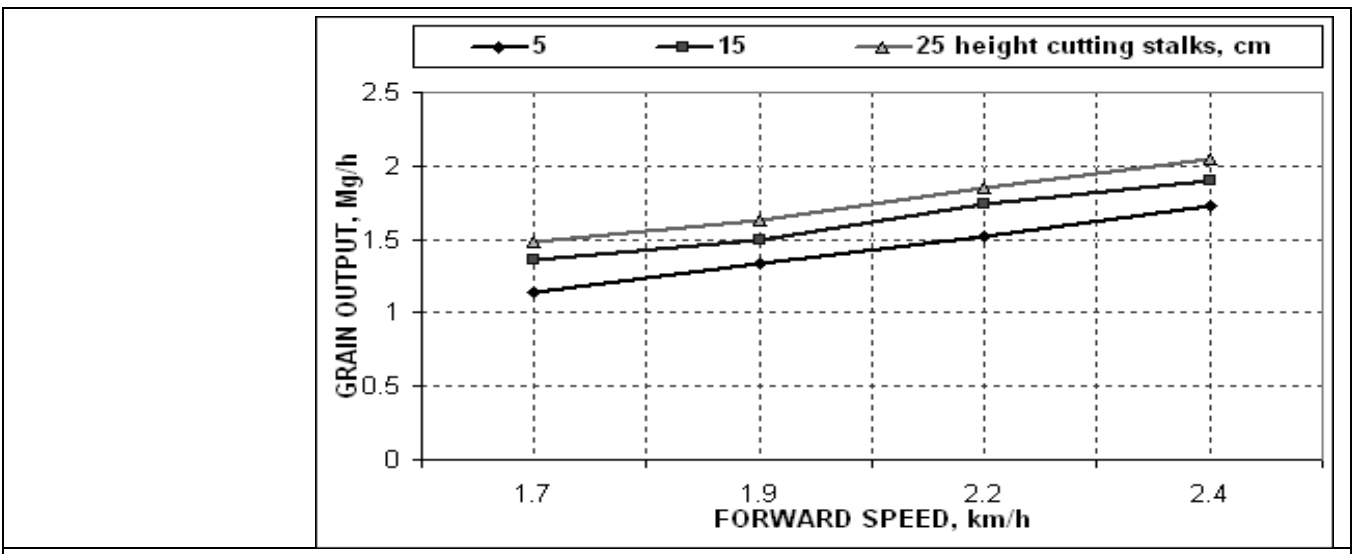

Fig. 7 .Effect of forward speed and height cutting stalks on grain output, $\mathrm{Mg} / \mathrm{h}$.

Table 3. Analysis of variance (mean squares) for variables evaluated

\begin{tabular}{|c|c|c|c|c|c|c|}
\hline Source & Actual Field Cal & $\begin{array}{c}\text { Field } \\
\text { Efficiency }\end{array}$ & $\begin{array}{l}\text { Grain } \\
\text { Output } \\
\end{array}$ & $\begin{array}{c}\text { Total Grain } \\
\text { Losses } \\
\end{array}$ & $\begin{array}{c}\text { Total Grain } \\
\text { Damage } \\
\end{array}$ & $\begin{array}{c}\text { Energy } \\
\text { Requirement } \\
\end{array}$ \\
\hline Blocks & $0.065269 * *$ & $0.079464 * *$ & $.2588 \mathrm{~ns}$ & $0.00881^{*}$ & $0.005869 * *$ & $0.00713 *$ \\
\hline \multicolumn{7}{|l|}{ Main Effects } \\
\hline Height Cutting Stalks & $4.598336 * *$ & $317.8047^{* *}$ & $1.2768^{* *}$ & $28.15089 * *$ & $4.28375 * *$ & $1620.168 * *$ \\
\hline Forward Speed & $3.249891 * *$ & $260.3747 * *$ & $2.1667 * *$ & $13.59187 * *$ & $1.164945^{* *}$ & $634.9762 * *$ \\
\hline Drum Speed & $4.798408 \mathrm{~ns}$ & $8.6759 \mathrm{~ns}$ & $3.5248 \mathrm{~ns}$ & $2.17172 * *$ & $1.136822 * *$ & $115.5242 * *$ \\
\hline \multicolumn{7}{|l|}{ Interaction } \\
\hline Height Cutting $\times$ Forward Speed & $0.117225^{* *}$ & $0.4503^{* *}$ & $0.0027 * *$ & $0.153485^{* *}$ & $0.039297 * *$ & $10.8497 * *$ \\
\hline Height Cutting $\times$ Drum Speed & $0.005325 \mathrm{~ns}$ & $8.6759 \mathrm{~ns}$ & $1.6553^{*}$ & $0.03146 * *$ & $0.00971^{* *}$ & $0.492284 * *$ \\
\hline Forward Speed $\times$ Drum Speed & $0.021556 *$ & $9.1204 * *$ & $1.8587 *$ & $0.01041^{* *}$ & $0.007945^{* *}$ & $1.104162^{* *}$ \\
\hline $\begin{array}{l}\text { Height Cutting } \times \text { Forward Speed } \\
\times \text { Drum Speed }\end{array}$ & $0.010917 * *$ & $9.1204 *$ & $2.4819 * *$ & $0.00447 * *$ & $0.011786 * *$ & $0.256672 * *$ \\
\hline
\end{tabular}

\begin{tabular}{|l|c|c|c|c|c|c|}
\hline Coefficient of determination $\left(\mathrm{R}^{2}\right)$ & 0.99498 & 0.9964 & 0.99936 & 0.99872 & 0.9980 & 0.9998 \\
\hline Coefficient of Variation (CV) & $0.889 \%$ & $0.1153 \%$ & $0.448 \%$ & $0.590 \%$ & $1.744 \%$ & $0.079 \%$ \\
\hline
\end{tabular}

** Significant at 0.01 level of probability,

* Significant at 0.05 level of probability,

ns Not significant.

\section{3- Total Grain Losses:}

Total grain losses were significantly influenced by height cutting stalks, forward speed and drum speed main effects as well as the following interactions: height cutting stalks $\times$ forward speed, height cutting stalks $\times$ drum speed, forward speed $\times$ drum speed and height cutting stalks $\times$ forward speed $\times$ drum speed (Table 3 ) with coefficient of determination $\left(R^{2}\right)$ of 0.9987 and coefficient of variation of $0.59 \%$. Fig. 8 show total grain losses as affected by different variables. The obtained results as shown in Table 4 indicated the relation between header losses and forward speed, 
drum speed and cutting height. Where, results indicate that, increasing forward speed and cutting height led to increase cutter bar losses.

The minimum of header losses was $2.10 \%$ recorded at forward speed of 1.7 $\mathrm{km} / \mathrm{h}$,drum speed of $12.39 \mathrm{~m} / \mathrm{s}$ and height cutting stalks of $25 \mathrm{~cm}$. Results indicated also that, increasing forward speed led to increase of grain losses in straw, while increasing cutting height and drum speed led to decrease of threshing losses. The minimum value of grain losses with straw was $0.96 \%$ recorded at forward speed of $1.7 \mathrm{~km} / \mathrm{h}$, drum speed of $12.39 \mathrm{~m} / \mathrm{s}$ and cutting height of $25 \mathrm{~cm}$ and maximum value of grain losses with straw was $1.8 \%$ recorded at forward speed of $2.8 \mathrm{~km} / \mathrm{h}$, drum speed of $18.32 \mathrm{~m} / \mathrm{s}$ and cutting height of $5 \mathrm{~cm}$. Also, data in Table 4 represented the effect of forward speed, drum speed and cutting height on unthreshed grain losses. Where, the increasing of forward speed led to increase of unthreshed grain losses. While, increasing both of drum speed and cutting height led to decrease of unthreshed grain losses. The maximum of unthreshed grain losses was $3.5 \%$ recorded at forward speed of $2.4 \mathrm{~km} / \mathrm{h}$, drum speed of $12.39 \mathrm{~m} / \mathrm{s}$ and cutting height of $5 \mathrm{~cm}$. Also, minimum of unthreshed grain losses was $1.5 \%$ recorded at forward speed of $1.7 \mathrm{~km} / \mathrm{h}$, drum speed of $18.32 \mathrm{~m} / \mathrm{s}$ and cutting height of $25 \mathrm{~cm}$.

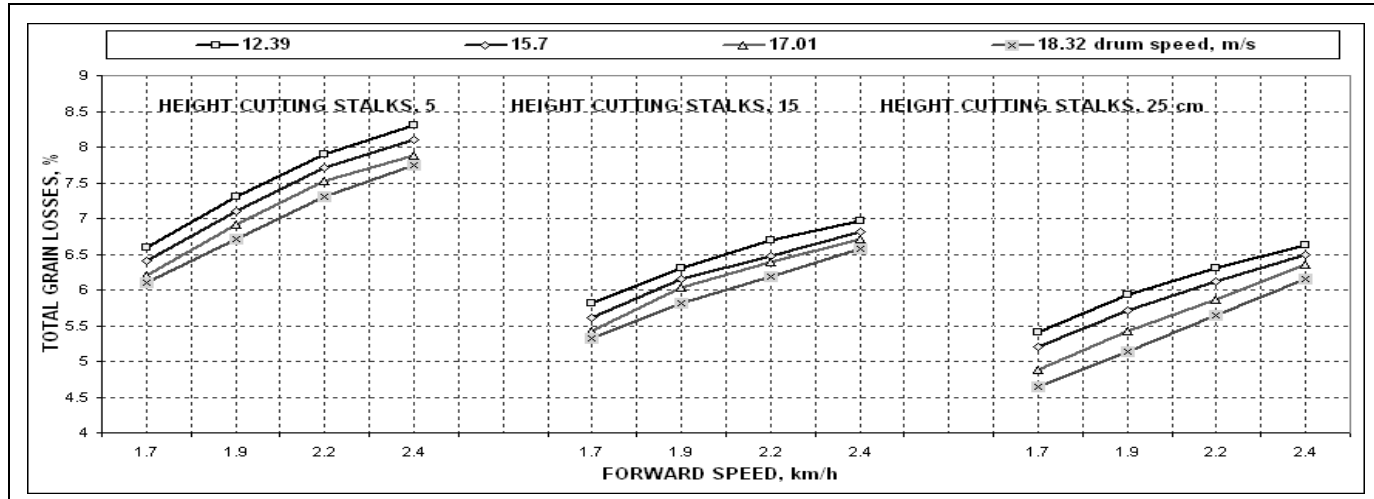

Fig. 8. Effect of forward speed and drum speed at different of height cutting stalks on total grain losses, \%. 
Table 4. Effect of forward speed and drum speed at different of height cutting stalks on header losses, unthreshed grain losses and grain losses in straw, \%.

\begin{tabular}{|c|c|c|c|c|c|c|c|c|c|c|c|c|c|}
\hline \multirow[t]{2}{*}{$\begin{array}{l}\text { height cutting } \\
\text { stalks, cm }\end{array}$} & & \multicolumn{4}{|c|}{$\begin{array}{c}\text { Header Losses, } \\
\%\end{array}$} & \multicolumn{4}{|c|}{ Unthreshed Grain Losses, \% } & \multicolumn{4}{|c|}{$\begin{array}{c}\text { Grain Losses In Straw, } \\
\%\end{array}$} \\
\hline & Forward speed, $\mathrm{km} / \mathrm{h}$ & 12.39 & 15.7 & 17.01 & 18.32 & 12.39 & 15.7 & 17.01 & 18.32 & 12.39 & 15.7 & 17.01 & 18.32 \\
\hline \multirow[t]{4}{*}{5} & 1.7 & 2.39 & 2.47 & 2.50 & 2.58 & 2.9 & 2.4 & 2.1 & 1.8 & 1.31 & 1.53 & 1.60 & 1.72 \\
\hline & 1.9 & 2.70 & 2.73 & 2.75 & 2.78 & 3.1 & 2.8 & 2.5 & 2.2 & 1.51 & 1.58 & 1.67 & 1.73 \\
\hline & 2.2 & 2.94 & 2.98 & 3.00 & 3.04 & 3.4 & 3.1 & 2.8 & 2.5 & 1.56 & 1.65 & 1.75 & 1.81 \\
\hline & 2.4 & 3.00 & 3.05 & 3.06 & 3.07 & 3.6 & 3.4 & 3.1 & 2.9 & 1.61 & 1.70 & 1.73 & 1.80 \\
\hline \multirow[t]{4}{*}{15} & 1.7 & 2.20 & 2.25 & 2.3 & 2.41 & 2.6 & 2.2 & 1.9 & 1.6 & 1.02 & 1.16 & 1.23 & 1.31 \\
\hline & 1.9 & 2.35 & 2.36 & 2.43 & 2.42 & 2.8 & 2.6 & 2.3 & 2.1 & 1.16 & 1.20 & 1.31 & 1.37 \\
\hline & 2.2 & 2.48 & 2.49 & 2.57 & 2.81 & 3.0 & 2.7 & 2.4 & 2.2 & 1.21 & 1.27 & 1.36 & 1.48 \\
\hline & 2.4 & 2.57 & 2.65 & 2.7 & 2.72 & 3.1 & 2.8 & 2.6 & 2.3 & 1.28 & 1.31 & 1.40 & 1.52 \\
\hline \multirow[t]{3}{*}{25} & 1.7 & 2.10 & 2.12 & 2.17 & 2.19 & 2.3 & 2.1 & 1.7 & 1.5 & 0.96 & 1.03 & 1.11 & 1.20 \\
\hline & 2.2 & 2.54 & 2.58 & 2.59 & 2.62 & 2.7 & 2.4 & 2.1 & 1.8 & 1.07 & 1.13 & 1.20 & 1.26 \\
\hline & 2.4 & 2.64 & 2.68 & 2.72 & 2.78 & 2.8 & 2.6 & 2.4 & 2.0 & 1.14 & 1.21 & 1.27 & 1.37 \\
\hline
\end{tabular}




\section{4- Total Grain Damage:}

Total grain damage contains visible grain damage and invisible grain damage that is reducing the quality of grain as it leads to a reduction in the percentage of germination. Analysis of variance indicated that total grain damage were significantly influenced by height cutting stalks, forward speed and drum speed main effects as well as the following interactions: height cutting stalks $\times$ forward speed, height cutting stalks $\times$ drum speed, forward speed $\times$ drum speed and height cutting stalks $\times$ forward speed $\times$ drum speed (Table 3 ) with coefficient of determination $\left(R^{2}\right)$ of 0.99801 and coefficient of variation of $1.744 \%$. Results in Fig. 9 show that, total grain damage (visible and invisible grain damage) was increased with increasing of drum speed and cutting height while it was decreased with increasing forward speed. Results as shown in Table 5 indicated also that, the minimum of visible and invisible grain damage were 0.18 and $0.23 \%$ recorded at forward speed of $2.4 \mathrm{~km} / \mathrm{h}$, drum speed of $12.39 \mathrm{~m} / \mathrm{s}$ and cutting height of $5 \mathrm{~cm}$. While the maximum of visible and invisible grain damage was 0.85 and $0.84 \%$ recorded at forward speed of $1.7 \mathrm{~km} / \mathrm{h}$, drum speed of $18.32 \mathrm{~m} / \mathrm{s}$, cutting height of $25 \mathrm{~cm}$.

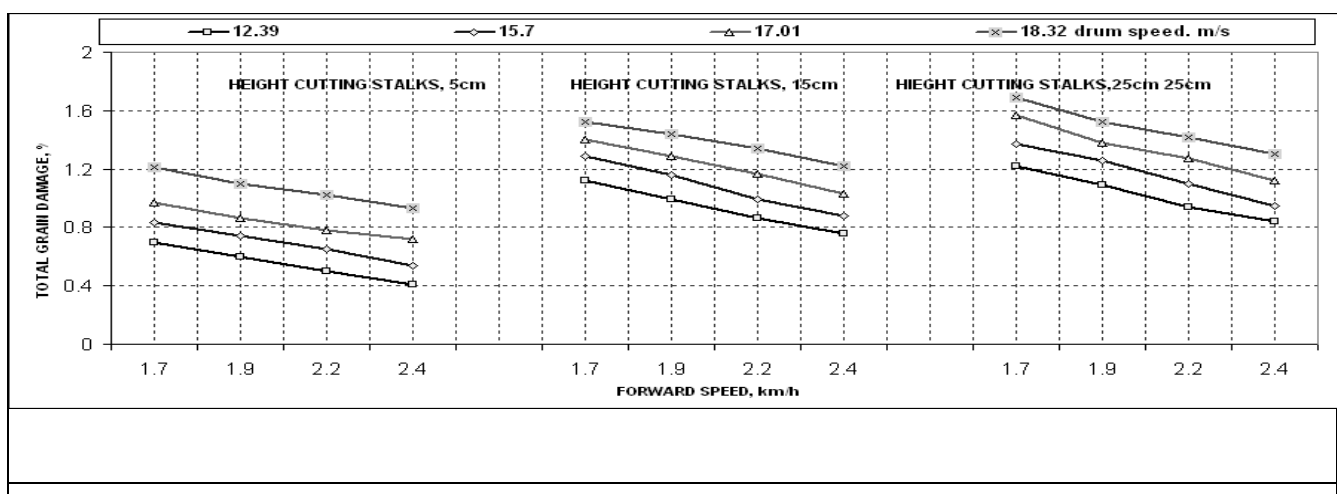

Fig. 9. Effect of forward speed and drum speed at different of height cutting stalks on total grain damage, $\%$. 
Table 5. Effect of forward speed, drum speed and cutting height on visible grain damage and invisible grain damage, $\%$.

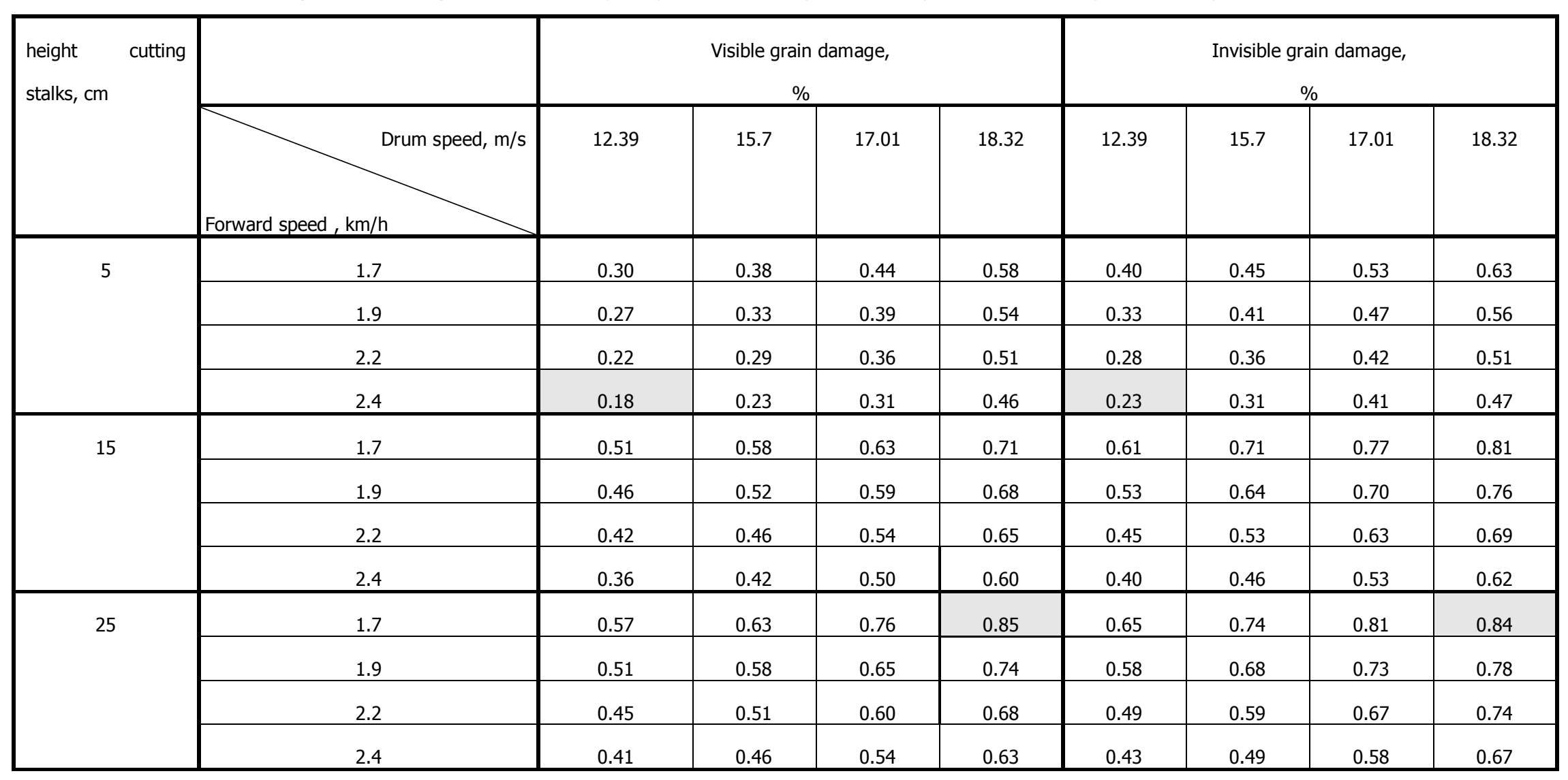




\section{5- Energy Requirement:}

The effects of forward speed, drum speed and height cutting stalks on energy requirement illustrated in Fig.10. Results noticed that, energy requirement led to decrease with increasing both of forward speed and height cutting stalks, while it was led to increase with increasing drum speed. Cutting height was more important factor affecting on energy requirement. Results also show that, low value of energy requirement was $25.87 \mathrm{kw} . \mathrm{h} / \mathrm{fed}$ recorded at forward speed of $2.4 \mathrm{~km} / \mathrm{h}$, drum speed of $12.35 \mathrm{~m} / \mathrm{s}$ and height cutting stalks of $25 \mathrm{~cm}$, respectively. Analysis of variance indicated that energy requirement was significantly influenced by cutting height stalks, forward speed and drum speed main effects as well as the following interactions: height cutting stalks $\times$ forward speed, height cutting stalks $\times$ drum speed, forward speed $\times$ drum speed and height cutting stalks $\times$ forward speed $\times$ drum speed (Table 3) with coefficient of determination $\left(R^{2}\right)$ of 0.9998 and coefficient of variation of $0.079 \%$.

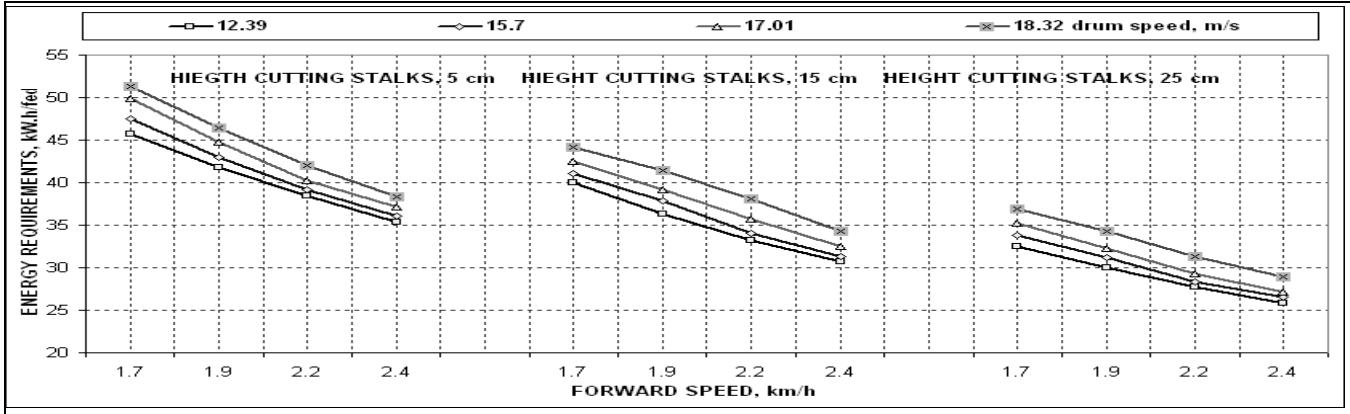

Fig. 10. Effect of forward speed and drum speed at different of height cutting stalks on energy requirement, kw.h/fed.

\section{CONCLUSION}

The obtained results of this study could be concluded as follows:

1- The development combine during harvesting Mexican Teosinte grain gave to maximum actual field capacity of $1.66 \mathrm{fed} / \mathrm{h}$, field efficiency of $69.1 \%$ and out put of $2.05 \mathrm{Mg} / \mathrm{h}$.

2- Minimum value of total grain losses was $4.96 \%$ recorded at forward speed of $1.7 \mathrm{~km} / \mathrm{h}$, drum speed of $18.32 \mathrm{~m} / \mathrm{s}$ and height cutting stalks of $25 \mathrm{~cm}$ respectively.

3- Minimum value of total grain damage was $0.41 \%$ recorded at forward speed of 2.4 $\mathrm{km} / \mathrm{h}$, drum speed of $12.39 \mathrm{~m} / \mathrm{s}$ and height cutting stalks of $5 \mathrm{~cm}$ respectively.

4- Minimum value of cutter bar losses, unthreshed grain losses and grain losses in straw were $2.1 \%, 1.5 \%$ and $0.96 \%$ respectively. While minimum value of visible grain losses and invisible grain losses were $0.18 \%$ and $0.23 \%$ respectively. 
5- Energy requirement was increased with increasing of drum speed and decreased with increasing both of forward speed and height cutting stalks. Also, minimum value of energy requirement was $25.87 \mathrm{~kW} . \mathrm{h} /$ fed recorded at forward speed of $2.4 \mathrm{~km} / \mathrm{h}$, drum speed of $12.39 \mathrm{~m} / \mathrm{s}$ and height cutting stalks of $25 \mathrm{~cm}$.

\section{REFERENCES}

1. AENRI. 2007. Final report developing of a medium size combine harvester for Egypt condition. Project Agric. Eng. Res. Inst. A.R.C. Egypt.

2. Elyamani, A.E., S.K., Genaidy, and A.M., Drees. 2012. Modification of Combine Harvester Header For Reaping Alfalfa. Egypt J.Agric.Res., 90 (3):1203-1221.

3. Hassani, H.S., A., Jafari, S.S., Mohtasebi and A.M., Setayesh. 2011. Investigation on Grain Losses of the JD 1165 Combine Harvester. American Journal of Food Technology 6 (4): 314-321.

4. Hunt, D. 1983. Farm power and machinery management. $8^{\text {th }}$ ed. Iowa State Univ., Press Ames, Iowa, USA: 364-368.

5. Mazaheri, D. 1997. Final report of future food plan, Islamic Republic of Iran Science, Agricultural science department.

6. Mosby, E. 1995. Combine harvester with secondary cutter. Ewen Mosby, Hartney, Manitoba. United States Patent No. 5,433,065. July 18

7. Mostofi, MR. 2011. Investigation and technical comparison of new and conventional wheat combines performance to improve and modification. Agricultural Engineering International: CIGR J. 13(3):63-68.

8. Mueller, S. C. 2008. Producing quality alfalfa grain for the forage industry. California Alfalfa \& Forage Symposium and Western Grain Conference, San Diego, CA, scmueller @ ucdavis.edu.

9. NSAE/NCAM/SON. 1995. Nigeria standard test code for grain and seed cleaners. Grain harvesters, and maize sheller, Nigeria Agricultural Engineering Standerds for the Nigerian society of Agricultural Engineers. Sponsored by National Centre for Agricultural mechanization and standards organization of Nigeria.

10. Oliveira, M.E.C., F.A.C., Almeida, F.M.M., Oliveira, J.J.S., Barros and J.P.G, Gouveia. 2005. Danificações em sementes de milho decorrentes da debulha e teor de umidade na colheita. Revista de Biologia e Ciências da Terra, v.5, n.2, http://eduep. uepb. edu. br./rbct/sumarios/pdf/danosmecanicos.pdf [ Links ] 
11. Ramesh K., J.R., Goss and S., Bob. 1980. Shatter Loss in Alfalfa Grain Harvesting. Trans of The ASABE. 23 (1): 0043-0046.

12. Siebenmorgen, T.J., S.B., Andrews, E. D., Vories and D. H., Loewer. 1994. Comparison of Combine Grain Loss Measurement Techniques. Applied Engineering in Agriculture. 10(3): 311-315.

13. Silberstein,T.B, M. E., Mellbye, T. G., Chastain and W. C. Young. 2010. Using Grain Moisture as a Harvest Management Tool. EM 9012. Oregon State University, extension service

14. Wilkes, H.G. 1997. Teosinte in México: Personal retrospective and assessment. J.A., M.C. Willcox, and F. Castillo- Gonzllez (ed.). Gene flow among maize landraces, improved maize varieties, and teosinte: Implications for transgenic maize. CIMMYT, México, D.F., Mexico. p. 10-17

15. Wilkes, G.H. 2004. Corn, strange and marvelous: But is a definitive teosinte origin known?. C.W. Smith (ed.) Corn: Origin, history, technology, and production. John Wiley \& Sons, Hoboken, NJ. p. 3-63. 


\section{تظوير آلة حصاد جامعة لتناسب الذرة الريانة}

\section{عاطف عزت اليماني ، أثرف السيد الثاذلي ، وائل فتحي المتولي}

$$
\text { معهز بحوث الهندسة الزراعبة - الدقي - الجيزة - مصر }
$$

تزرع الذرة الريانة كحصول علف أخضر صيفي. حيث تعطى الذرة الريانة ثلاث حشات وىىستعمل

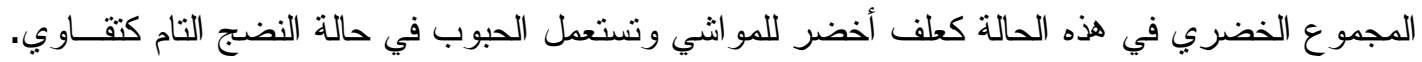

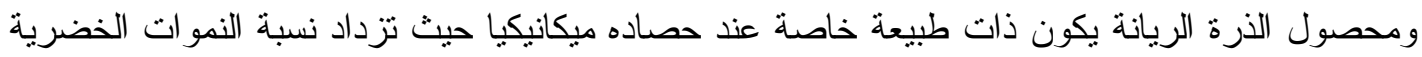

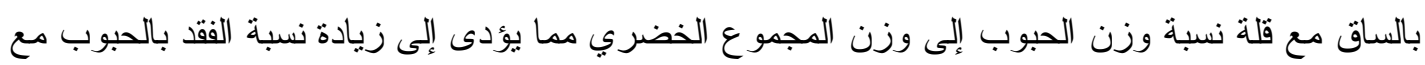

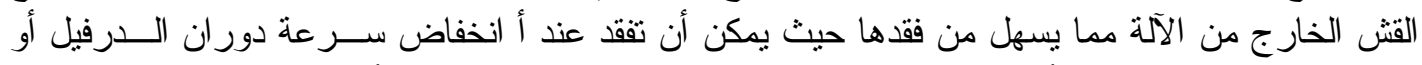

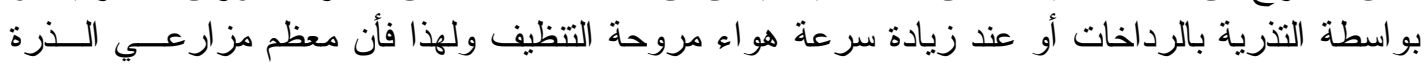

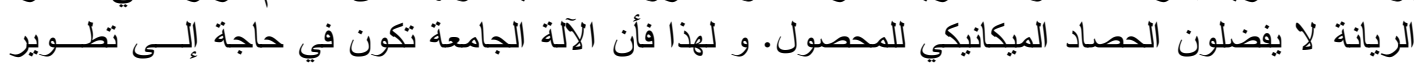

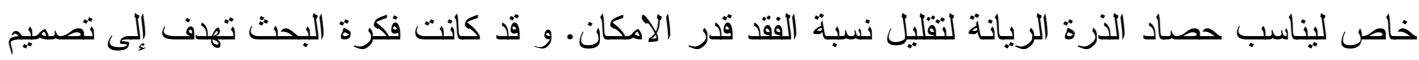

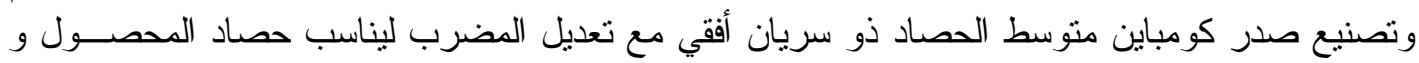

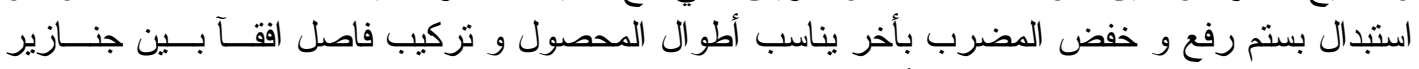

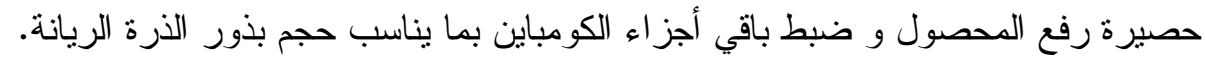

\section{المعاملات التجريبية للار اسة:}

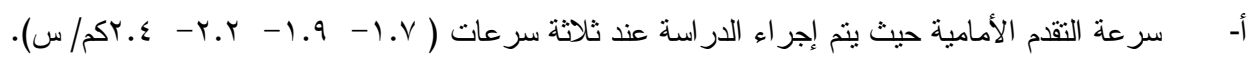

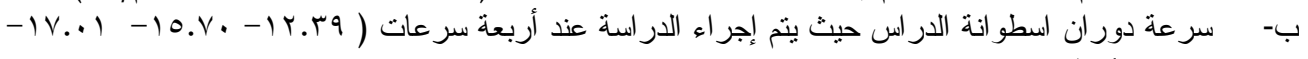

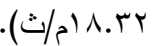

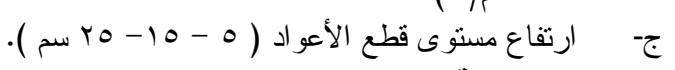
القياسات المطلوية:

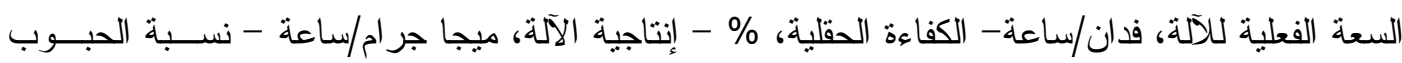

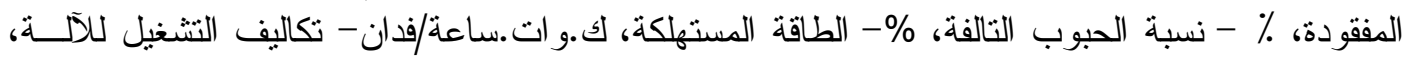

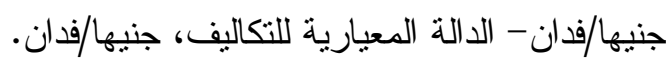
وقا أمكن الحصول على النتائج التالبة:-

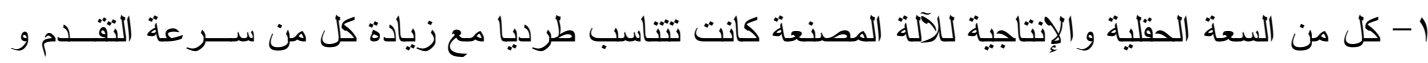

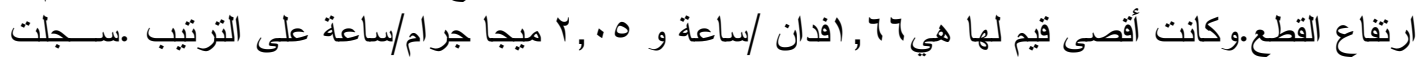

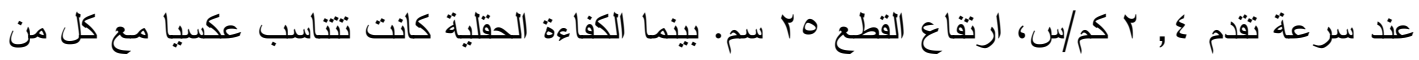

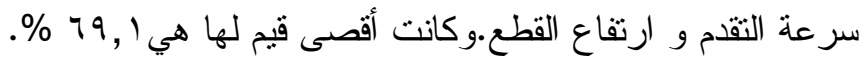

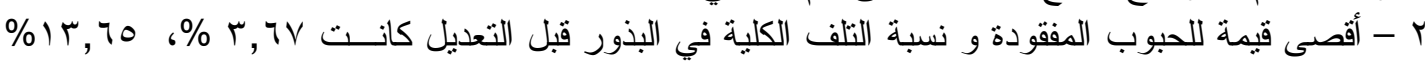

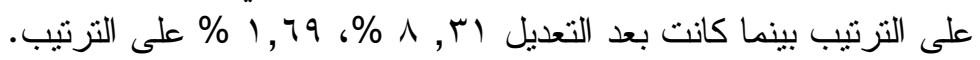

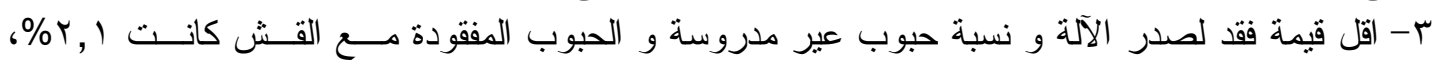

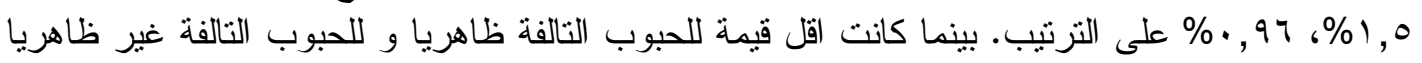

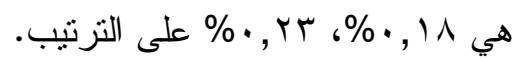

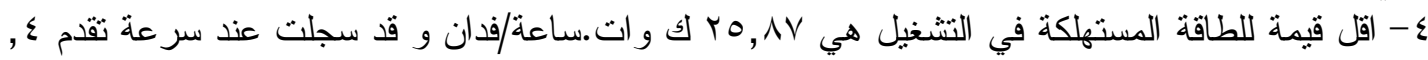

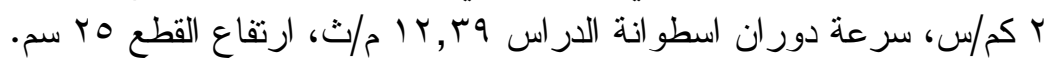

